[計 測 自動制 御 学 会 論文集]

[ Vol.48, No.4, 207/213 (2012) ]

\title{
遷移沸騰領域における冷却制御のモデリングと安定性解析
}

\author{
中 川 繁 政*・平 田 健太郎**・杉 本 謙 二**
}

\section{Modeling and Stability Analysis of Cooling Control in the Transition Boiling Region}

\author{
Shigemasa Nakagawa*, Kentaro Hirata** and Kenji Sugimoto**
}

\begin{abstract}
This paper proposes a new model for cooling control in the transition boiling region. The temperature dependence of the cooling process gain is expressed via a nonlinear state space form. The stability of cooling control is analyzed by applying the sum of squares technique to this model. Simulation results show that the gain of PI controller should be reduced as target temperatures become small in the transition boiling region.
\end{abstract}

Key Words: cooling control, modeling, stability analysis, feedback control, transition boiling region

\section{1. 緒言}

近年，地球温暖化対策として $\mathrm{CO}_{2}$ 削減が大きな問題となっ ており，自動車用素材である薄鋼板についても，自動車軽量 化の観点から, 高強度で加工性の良い高張力鋼板のニーズが 増えてきている.

熱延薄鋼板における高張力鋼板（以下，熱延高張力鋼板） は, 熱延ミルと呼ばれる設備において, $1200^{\circ} \mathrm{C}$ 近辺まで加 熱されたスラブ（約 $270 \mathrm{~mm}$ 厚）から圧延ロールにて熱間圧 延され，所望の板厚まで薄くされた後に，ランアウトテーブ ル冷却装置で所定の温度（巻取温度という）まで泠却されて 製造される.この際, 熱延高張力鋼板の製品特性は, 巻取温 度の影響を強く受けるため, 巻取温度制御の高精度化は重要 な課題である。

巻取温度制御では，従来より各種の取り組みがなされてき ているが，鋼板の巻取温度予測に基づくフィードフォワード 制御が基本となっている ${ }^{1) ~ 3)}$. もっとも実際の操業において は, 巻取温度計算值と巻取温度測定値との間の誤差の発生は 不可避であるため, 実績巻取温度が目標巻取温度に一致する ようにフィードバック制御が併せて実施される。このフィー ドバック制御には, 巻取温度計にできるだけ近接した冷却バ ンクをフィードバック専用の冷却バンク (バーニアバンクと称 される）として使用する方法が通常行なわれている2),4) -6).

* 住友金属工業（株）総合技術研究所 鹿嶋市光 3 番地

** 奈良先端科学技術大学院大学情報科学研究科 生駒市高山町 8916-5

* Corporate Research \& Development Laboratories, Sumitomo Metal Industries, Ltd., 3 Hikari, Kashima

** Graduate School of Information Science, Nara Institute of Science and Technology, 8916-5 Takayama-cho, Ikoma (Received January 28, 2011)

(Revised February 22, 2012)
一般に熱延高張力鋼板の製造では，目標巻取温度が比較的 低温（550 $\mathrm{C}$ 以下）に設定されることが多い。この温度領域 は後述するように遷移沸騰領域と呼ばれ，鋼板表面での水冷熱 伝達率変化がそれ以上の温度域に比べて大きく変化する ${ }^{7), 8)}$. その結果として巻取温度制御精度が悪化することが, 従来よ り問題とされてきた。成田ら ${ }^{7)}$ は, 見かけ上のプロセスゲイ ンの増大に伴い制御系が不安定となることが精度悪化につな がっていると考察している。しかしながらこれまではどちら かといえば現象の定性的な理解にとどまっており，プロセス ゲインが状態量の一つである温度に依存するという非線形挙 動のモデル化や安定性解析などの定量的な検討は行なわれて こなかった。

一方, 非線形システムの安定性解析や制御系設計に有効な 手法として多項式二乗和（Sum Of Squares）を用いた方法が 近年開発されてきている ${ }^{9) \sim 13)}$. 多項式二乗和に基づくロバ スト制御系設計 ${ }^{11)}$, Prajna ら ${ }^{9)}$ による非線形システムの制 御系設計方法の開発，加藤ら ${ }^{10)}$ による状態依存むだ時間系に 対する安定性解析への応用，青木ら ${ }^{12)}$ や市原ら ${ }^{13)}$ によら インスケジューリング制御への応用などがその一例である.

そこで, 本論文では, 冷却工程のプロセスゲインが鋼板温 度に依存するという前提のもとで, 冷却制御の非線形状態空 間モデルを導き，遷移沸騰領域における冷却制御の安定性解 析を行なうことを目的とする。

本論文の構成は以下のとおりである。まず，第 2 章では， 遷移沸騰熱伝達の概要とそのモデル化について述べる．第 3 章では，遷移沸騰領域での冷却制御のモデリングについて記 す. 第 4 章では, 多項式二乗和に基づく方法を用いて冷却制 御の安定性解析を行なう。第 5 章では, 数值実験による冷却 制御の安定性解析結果を示し, 遷移沸騰領域でのパラメー夕 変化と安定化限界ゲインの関係について述べる. 


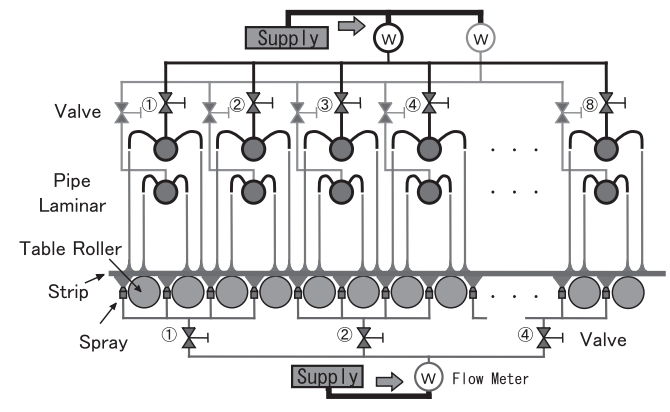

Fig. 1 Cooling process

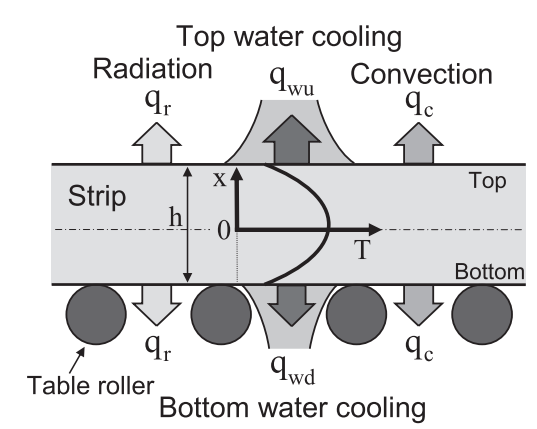

Fig. 2 Boundary condition of strip surface

\section{2. 鋼板冷却にける遷移沸騰熱伝達}

本章では，鋼板冷却における遷移沸騰熱伝達の概要とその モデル化について説明した後に，本研究の動機付けとして， 目標巻取温度が遷移沸騰領域にあるような低温巻取材（目標 巻取温度が抢抢むね $550^{\circ} \mathrm{C}$ 以下) での冷却制御の課題につい て述べる。

\section{1 遷移沸騰熱伝達のモデル化}

熱延ミルでは，仕上圧延後の鋼板を Fig. 1 に示すような冷 却装置にて上下面から水冷する。この際，冷却過程における 鋼板温度は, 次式に示す板厚方向 1 次元熱伝導方程式により 表わされる2).

$$
c(T) \rho \frac{\partial T}{\partial t}=\frac{\partial}{\partial x}\left(\lambda(T) \frac{\partial T}{\partial x}\right)
$$

ここで, $T$ は鋼板温度, $x$ は板厚方向位置， $t$ は時間， $c, \rho$, $\lambda$ はそれぞれ鋼板の比熱，密度，熱伝導率である（Fig. 2).

鋼板の上面および下面における境界条件は，以下のように 与えられる。

$$
\begin{aligned}
& -\left.\lambda(T) \frac{\partial T}{\partial x}\right|_{x=h / 2}=q_{r}+q_{c}+q_{w u} \\
& -\left.\lambda(T) \frac{\partial T}{\partial x}\right|_{x=-h / 2}=-\left(q_{r}+q_{c}+q_{w d}\right)
\end{aligned}
$$

ここで, $h$ は板厚, $q_{w u}, q_{w d}$ は上面および下面の水冷熱流束, $q_{c}, q_{r}$ はそれぞれ対流熱流束, 輻射熱流束である.

輻射熱流束 $q_{r}$ は, ステファン・ボルッマンの法則より, 次 式で与えられる。

$$
q_{r}=\sigma \epsilon\left\{\left(\frac{T_{s}+273}{100}\right)^{4}-\left(\frac{T_{a}+273}{100}\right)^{4}\right\}
$$

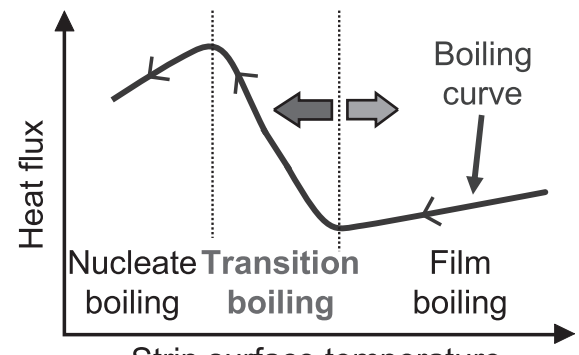

Strip surface temperature

Fig. 3 Boiling curve

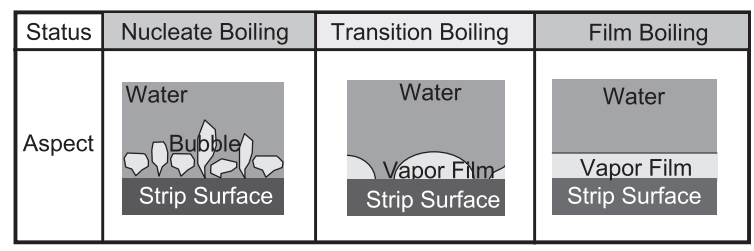

Fig. 4 Schematic diagram of three kinds of boiling

ここで， $T_{s}, T_{a}$ はそれぞれ鋼板表面温度，雲囲気温度であり， $\sigma$ はステファン・ボルツマン定数， $\epsilon$ は放射率である.

また，対流熱流束 $q_{c}$ は， $H_{a}$ を対流熱伝達率として，下記 で与えられる。

$$
q_{c}=H_{a}\left(T_{s}-T_{a}\right)
$$

鋼板が冷却される際の水冷熱流束は, Fig. 3 に示す沸騰曲 線からわかるように，膜沸騰状態から遷移沸騰状態に推移す ると急激に増加する。これは，鋼板表面全体で鋼板と冷却水 の間に蒸気膜が存在する膜沸騰状態では水冷熱伝達率がほぼ 一定で熱流束変化が少ないのに対し，蒸気膜が部分的に崩壊 する遷移沸騰状態では現象が非定常になり，水冷熱流束の大 幅な変動が生じることに起因する（Fig. 4).

そこで，水冷熱流束については，冷却過程の沸騰熱伝達機 構に着目して，つぎのようなモデルを考える ${ }^{14)}$. 以下では, 上表面の水冷熱流束 $q_{w u}$ についてのみ記すが，下表面につい ても同様である。なお， $u$ は上面を表わす添え字とする.

水冷熱流束が極小になる温度を極小熱流束 $(\mathrm{MHF})$ 点と呼 び，このときの温度を $T_{\mathrm{MHF}}$ で表わす．また水冷熱流束が極 大になる温度を限界熱流束 $(\mathrm{CHF})$ 点と呼び，このときの温 度を $T_{\mathrm{CHF}}$ で表わす。これらは, Dhir-Puroit の定式化 ${ }^{15)} に$ 従い，サブクール度 $\Delta T_{\mathrm{SUB}}$ を用いて，以下のようにモデル 化できる.

$$
\begin{aligned}
& \Delta T_{\mathrm{SUB}}=T_{\mathrm{SAT}}-T_{w} \\
& T_{\mathrm{MHF}}=T_{m 0}+T_{m 1} \Delta T_{\mathrm{SUB}} \\
& T_{\mathrm{CHF}}=T_{c 0}+T_{c 1} \Delta T_{\mathrm{SUB}}
\end{aligned}
$$

ここで， $T_{\mathrm{SAT}}, T_{w}$ はそれぞれ冷却水飽和温度, 冷却水温度, $T_{m 0}, T_{m 1}, T_{c 0}, T_{c 1}$ は $\mathrm{MHF}$ 点温度および $\mathrm{CHF}$ 点温度に かかわる定数である.

(A) 膜沸騰領域 $\left(T_{s} \geq T_{\mathrm{MHF}}\right)$

$$
q_{w u}=q_{F, u}=H_{F, u}\left(T_{s, u}-T_{w}\right)
$$




$$
H_{F, u}=b_{u} W_{u}^{{ }^{c}{ }_{u}} V^{e}\left(1+r \Delta T_{\mathrm{SUB}}\right)^{-1}
$$

ここで, $q_{F, u}$ は膜沸騰領域での水冷熱流束, $H_{F, u}$ は膜沸騰 領域での水冷熱伝達率, $T_{s, u}$ は鋼板表面温度, $W_{u}$ は冷却水 量密度, $V$ は鋼板速度, $b_{u}, c_{u}, e, r$ は膜沸騰領域での水冷 熱伝達率にかかわる定数である.

(B) 核沸騰領域 $\left(T_{s} \leq T_{\mathrm{CHF}}\right)$

通常, 目標巻取温度はこの温度範囲外にあるので，ここで は $T_{s}=T_{\mathrm{CHF}}$ における限界熱流束の算出のみに使用する.

$$
q_{w u}=q_{N, u}=a_{u} W_{u}{ }^{c_{u}} V^{e}
$$

ここで, $q_{N, u}$ は限界熱流束, $a_{u}$ は限界熱流束にかかわる定 数である.

（C）遷移沸騰領域 $\left(T_{\mathrm{CHF}}<T_{s}<T_{\mathrm{MHF}}\right)$

固液接触の空間平均に関する Kalinin らの考え方 ${ }^{16)}$ に従 い, 固液接触面積割合 $F_{u}$ を用いて, 以下のように考える.

$$
\begin{aligned}
& q_{w u}=q_{t, u}=F_{u} q_{N, u}+\left.\left(1-F_{u}\right) q_{F, u}\right|_{T_{s, u}=T_{\mathrm{MHF}}} \\
& F_{u}=\frac{T_{\mathrm{MHF}}-T_{s, u}}{T_{\mathrm{MHF}}-T_{\mathrm{CHF}}}
\end{aligned}
$$

水冷熱流束については, 鋼板の表面温度に応じて, 膜沸騰 領域では (9) 式を, 遷移沸騰領域では (12) 式を用いる. 水冷熱伝達率 $h_{w u}$ は, 水冷熱流束 $q_{w u}$ より求められる.

$$
h_{w u}=q_{w u} /\left(T_{s, u}-T_{w}\right)
$$

冷却過程における鋼板温度は, 熱伝導方程式 (1) を境界条 件 (2) 式，(3) 式のもとで, 有限差分法を用いて解くことによ り，計算することができる。

上記に提案した遷移沸騰熱伝達率モデルを用いて, 仕上圧 延機出側温度 $F T$ を初期温度として, 中間温度 $I T$ および 巻取温度 $C T$ を計算した例（板厚 $4.54 \mathrm{~mm}$, 目標巻取温度 $430^{\circ} \mathrm{C}$, サンプリング間隔 $5.6 \mathrm{~m}$ ）を Fig. 5 に示す. 中間温 度計算值 $I T_{c a l}$, 巻取温度計算值 $C T_{c a l}$ ともに, それぞれ中間 温度実績值 $I T_{a c t}$, 巻取温度実績值 $C T_{a c t}$ に全長にわたって お抄むね一致していることがわかる，また，本提案モデルに よる水冷熱伝達率の変化を Fig. 6 に示す．遷移沸騰領域での 鋼板冷却に際し, 鋼板表面温度の低下に伴い水冷熱伝達率が 高くなるモデルになっていることがFig. 6 からわかる. なお， Fig. 6 中の水冷熱伝達率は冷却水量密度を $W=1$ に換算し たもので表わしている，また，熱流束に関するパラメータは， $a_{u}=1.4 \times 10^{6}, b_{u}=1.167 \times 10^{3}, c_{u}=0.425, e=-0.08$, $r=1.667 \times 10^{-3}$ とした.

さらに実機試験の結果として, 提案モデルを用いた巻取温 度計算值と巻取温度実績值の比較を Fig. 7 に示す。ここで, Fig. 7 中のプロットは計算值, 実績值ともコイル中央部の平均 值としている. 冷却水温 $T_{W}=38^{\circ} \mathrm{C}$ のオフラインデータに よる結果, および, $T_{W}=33^{\circ} \mathrm{C}$ の実機試験結果データとも, 巻 取温度計算值がおおむね $\pm 20^{\circ}$ の精度で計算できていること がわかる（実機試験結果に対する計算温度偏差の $\bar{x}=5.7^{\circ} \mathrm{C}$,

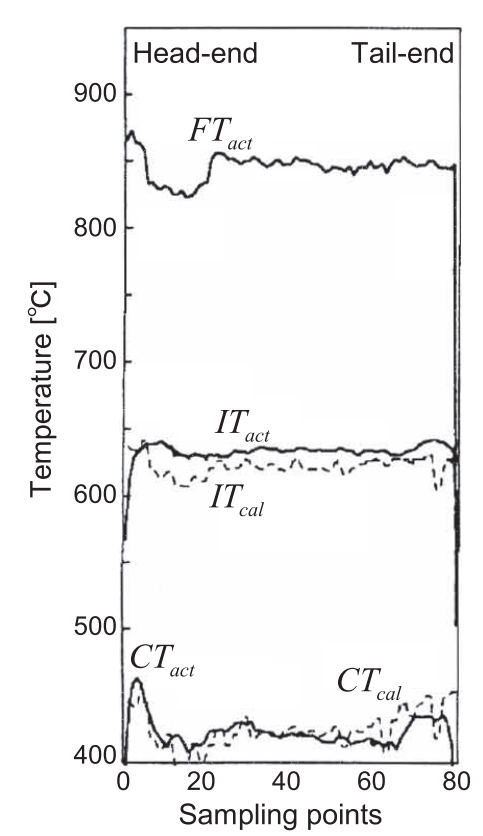

Fig. 5 Calculated temperatures using the proposed heat transfer coefficient model in the transition boiling region (FT: finishing temperature, IT: intermediate temperature, $C T$ : coiling temperature)

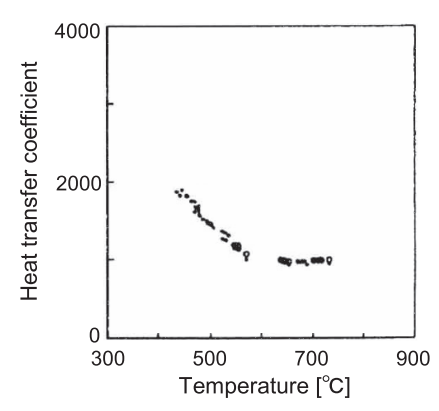

Fig. 6 Calculated heat transfer coefficient by the proposed model (converted value so that $W=1$ )

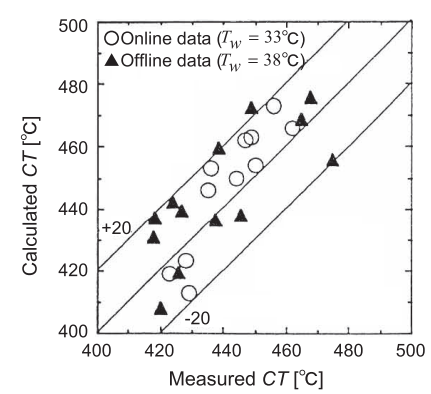

Fig. 7 Calculated $C T$ vs. measured $C T$ (mean temperatures in the middle points of the strips)

$$
\left.\sigma=10.6^{\circ} \mathrm{C}\right) \text {. }
$$

\section{2 遷移沸騰領域における冷却制御の課題}

遷移沸騰領域においては, Fig. 6 からもわかるように鋼板 冷却に際して水冷熱伝達率が大きく変化する，このため，目 標巻取温度が遷移沸騰領域にある低温巻取材では巻取温度制 御精度が悪化する $\left.\left.{ }^{3)}, 7\right), 8\right), 17$. 
成田ら ${ }^{7), 8)}$ は低温巻取材の安定製造を図るための手段とし て緩冷却ノズルの開発を行なっている。また，中川ら ${ }^{3)}$ は， 遷移沸騰領域での水冷の不安定性を回避するため，バーニア バンク型のフィードバック制御 ${ }^{18)}$ を用いずに，鋼板冷却のダ イナミック制御（鋼板上に複数の仮想的な制御点を設け，制 御点の位置をトラッキングしながら各制御点の温度予測計算 を行ない，予測温度が目標温度と一致するように冷却装置の 設定計算を行なう方式）が狙う目標值を巻取温度偏差（=目 標巻取温度 - 実績巻取温度) に基づき PI 制御する方法を提 案している。しかしながら，この方法は実績巻取温度による フィードバック制御をダイナミック制御の目標值変更を通し て間接的に行なうため，応答性の面で問題がある。

本来，実績巻取温度を用いたフィードバック制御には，応 答性の面からはバーニアバンク型が望ましく，実際，目標巻 取温度が膜沸騰領域にある場合，あるいはお打むね $550^{\circ} \mathrm{C}$ 以 上の場合にはバーニアバンク型のフィードバック制御が実用 化されている18),19).

したがって，目標巻取温度が遷移沸騰領域にあるような低 温巻取材に対して，バーニアバンク型のフィードバック制御 を適用し巻取温度制御の高精度化を図るには，遷移沸騰領域 での鋼板冷却に関して，鋼板温度に依存した冷却制御のモデ リングを行ない，遷移沸騰冷却に扔けるプロセスゲインと制 御系安定性の関係を明らかにすることが必要である.

\section{3. 遷移沸騰領域における冷却制御のモデリング}

前章では，鋼板水冷時の鋼板温度の変化を表わす物理モデ ル (1) と遷移沸騰熱伝達の物理モデル (12), (13), (14) につ いて説明したが，本章では，次章で行なう安定性解析の準備 として，遷移沸騰領域に扔ける冷却制御に関し，非線形状態 方程式によるモデリングを行なう。

鋼板温度に関しては巻取温度計位置での鋼板温度に着目し， 鋼板温度の内部温度分布については代表点 1 点で集中化でき るものとする，また，熱流束あるいは熱伝達率については， 上下面の平均值で考えるものとする ${ }^{2)}$.

上記の前提で，仕上出口温度からの温度降下量に着目して 冷却制御のモデリングを行なう。ここでは, Hinrichsen ら ${ }^{6)}$ にて取り上げられている冷却スプレーが集中化した制御系を 考えることとする。制御系のブロック線図を Fig. 8 に示す. 冷却工程を 1 次遅れ系のプロセスと考え，冷却工程による温 度降下量が目標温度降下量となるように PI 制御器にて冷却 スプレーバルブを制御する系である。ただし，移送遅れのむ だ時間 $T_{d}$ については，冷却帯内の注水環境下で鋼板温度を 高精度に測温できる温度計（ファウンテン・パイロメーター） の開発 20), 21) などによって近年ますます計測むだ時間を低減 できる方向にあり，ここでは $T_{d}=0$ とする。

膜沸騰領域の水冷熱伝達率の変化は遷移沸騰領域のそれに 比べてかなり小さいので，一定と近似してよい．これは以下 の $(15)$ 式のプロセスゲイン $K_{C}$ を固定值にとることに相当 する ${ }^{6)}$ 。一方，本論文では遷移沸騰領域での鋼板冷却を考え

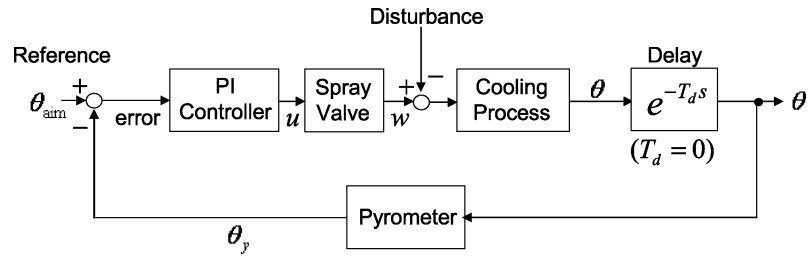

Fig. 8 Block diagram

るので，(12）式に基づいて，プロセスゲイン $K_{C}$ をつぎの ようにモデル化する。

$$
K_{C}=\beta\left(\theta-\theta_{\mathrm{MHF}}\right)+\alpha_{0} \quad\left(\theta>\theta_{\mathrm{MHF}}\right)
$$

ここで, $\theta$ は鋼板温度の仕上温度 $F T$ からの温度降下量, $\theta_{\mathrm{MHF}}$ は仕上温度 $F T$ からの温度降下量で表現した鋼板の MHF 点, $\alpha_{0}>0$ は MHF 点でのプロセスゲインに相当するパラメー 夕， $\beta>0$ はプロセスゲインの温度依存性を表わすパラメー タである。

温度計の特性を次式で表わす。

$$
\frac{d}{d t} \theta_{y}(t)=\frac{1}{T_{Y}}\left(K_{Y} \theta(t)-\theta_{y}(t)\right)
$$

ここで, $\theta_{y}$ は鋼板温度の仕上温度からの温度降下量計測値, $K_{Y}, T_{Y}$ はそれぞれ温度計特性のゲインおよび時定数である. 冷却工程の特性を次式で表わす。

$$
\frac{d}{d t} \theta(t)=\frac{1}{T_{C}}\left\{K_{C}(w(t)-d(t))-\theta(t)\right\}
$$

ここで, $w$ は冷却水量, $d$ は外乱, $T_{C}$ は冷却工程の時定数で ある。

冷却スプレーバルブの特性を次式で表わす.

$$
\frac{d}{d t} w(t)=\frac{1}{T_{V}}\left(K_{V} u(t)-w(t)\right)
$$

ここで， $u$ は PI 制御器の出力， $K_{V}, T_{V}$ はそれぞれバルブ 特性のゲインおよび時定数である。

PI 制御器を次式で表現する.

$$
u(t)=K_{P}\left\{\left(\theta_{\mathrm{aim}}-\theta_{y}(t)\right)+\frac{1}{T_{I}} \int_{0}^{t}\left(\theta_{\mathrm{aim}}-\theta_{y}(\tau)\right) d \tau\right\}
$$

ここで， $\theta_{\text {aim }}$ は仕上温度からの温度降下量で表現した鋼板の 目標温度， $K_{P}, T_{I}$ はそれぞれ $\mathrm{PI}$ 制御器の比例ゲインおよ び時定数である.

このとき, 平衡点からの偏差を考え, 状態量 $x(t)=$ $\left[x_{1}(t), x_{2}(t), x_{3}(t), x_{4}(t)\right]^{T} \in R^{4}$ を以下のようにとる.

$$
\begin{aligned}
& x_{1}(t)=w(t)-\frac{\theta_{\text {aim }}}{K_{Y} K^{*}} \\
& x_{2}(t)=\theta(t)-\frac{\theta_{\text {aim }}}{K_{Y}} \\
& x_{3}(t)=\theta_{y}(t)-\theta_{\text {aim }} \\
& x_{4}(t)=\int_{0}^{t}\left(\theta_{y}(\tau)-\theta_{\text {aim }}\right) d \tau+\frac{\theta_{\text {aim }}}{g K_{V} K_{P} K_{Y} K^{*}}
\end{aligned}
$$




$$
K^{*}=\beta\left(\frac{\theta_{\text {aim }}}{K_{Y}}-\theta_{\mathrm{MHF}}\right)+\alpha_{0}
$$

である。また, $g=1 / T_{I}$ である。

このとき，次式のような非線形状態空間モデルを導くこと ができる。

$$
\frac{d}{d t} x(t)=A(x) x(t)+E(x) d(t)
$$

ここに, $A(x), E(x)$ は $x$ に依存した行列で, それぞれ $(26)$, (27) 式で与えられる.

$$
\begin{aligned}
& A(x)=\left[\begin{array}{cccc}
-\frac{1}{T_{V}} & 0 & -\frac{K_{V} K_{P}}{T_{V}} & -\frac{K_{V} K_{P}}{T_{V} T_{I}} \\
\frac{K^{*}+\beta x_{2}}{T_{C}} & \frac{\beta \theta_{\text {aim }}-K_{Y} K^{*}}{T_{C} K_{Y} K^{*}} & 0 & 0 \\
0 & \frac{K_{Y}}{T_{Y}} & -\frac{1}{T_{Y}} & 0 \\
0 & 0 & 1 & 0
\end{array}\right] \\
& E(x)=\left[\begin{array}{c}
0 \\
-\frac{K^{*}+\beta x_{2}}{T_{C}} \\
0 \\
0
\end{array}\right]
\end{aligned}
$$

\section{4. 安定性解析の手法}

本章では，前章の冷却制御のモデリングに基づき，遷移沸 騰領域における冷却制御の安定性解析を行なう.

以下では，フィードバック制御系の安定性を考察するため, つぎのシステムを考える。

$$
\frac{d}{d t} x(t)=A(x) x(t)
$$

一般に，(28) 式のような非線形システムに対して大域的な Lyapunov 関数を見つけることは容易ではないため, Prajna らによる多項式二乗和による局所安定解析法 $\left.{ }^{9)}, 10\right)$ を適用する.

【定義 1】ベクトル変数 $z=\left[z_{1}, \cdots, z_{p}\right]^{T}$ に対するスカラ関 数 $\psi(z)$ が

$$
\psi(z)=\sum_{j=1}^{N} \phi_{j}(z)^{2}, \phi_{j}(z): z_{1}, \cdots, z_{p} \text { の多項式 }
$$

のように表わされるとき, 多項式二乗和 (以下ではSOS (Sum Of Squares) と略記) であるという.

このとき，以下の定理が知られている.

【定理 1】 ${ }^{9)}$ 領域 $X$ を関数 $g(\cdot)$ と正数 $\gamma$ を用いて以下のよう に定める.

$$
\begin{aligned}
& g(x)=\left(\gamma^{2}-\|x\|^{2}\right) / \gamma^{2} \\
& X \equiv\left\{x \in R^{n} \mid g(x)>0\right\}
\end{aligned}
$$

このとき，

$$
\begin{aligned}
& V(x)-\sigma_{1}(x) g(x)-\epsilon_{1}\|x\|^{2} \text { は SOS } \\
& -\sum_{i=1}^{n} \frac{\partial V(x)}{\partial x_{i}} \dot{x_{i}}-\sigma_{2}(x) g(x)-\epsilon_{2}\|x\|^{2} \text { は SOS }
\end{aligned}
$$

となるような関数 $V(\cdot)$, 定数 $\epsilon_{1}>0, \epsilon_{2}>0$ および $\mathrm{SOS}$ 関
Table 1 Simulation parameters

\begin{tabular}{|c|c||c|c||c|c|}
\hline$\beta$ & 0.222 & $F T$ & 850 & $K_{V}$ & 1.0 \\
\hline$\alpha_{0}$ & 22.2 & $T_{\mathrm{MHF}}$ & 600 & $T_{V}$ & 0.5 \\
\hline$T_{I}$ & 10 & $\theta_{\mathrm{MHF}}$ & 250 & $K_{Y}$ & 1.0 \\
\hline$T_{C}$ & 5.0 & $T_{d}$ & 0.0 & $T_{Y}$ & 1.0 \\
\hline
\end{tabular}

数 $\sigma_{1}(\cdot), \sigma_{2}(\cdot)$ が存在するならば, 領域 $X$ においてシステム (28)の原点は局所漸近安定である.

以下の安定性解析では, 計算上の複雑さを減らすために Lyapunov 関数のクラスを 2 次形式に限定する。このとき, 以下 の系が直ちに導かれる。

【系 2】 ${ }^{9)}$ システム $(28)$ と領域 $X(31)$ が与えられていると する.このとき, 対称行列 $P$, 定数 $\epsilon_{1}>0, \epsilon_{2}>0$, 㧍よび $\operatorname{SOS}$ 関数 $\sigma_{1}(\cdot), \sigma_{2}(\cdot)$ が存在し，以下の条件を満足するもの とする。

$$
\begin{aligned}
& x^{T} P x-\sigma_{1}(x) g(x)-\epsilon_{1}\|x\|^{2} \text { はSOS, } \\
& -x^{T}\left\{A(x)^{T} P+P A(x)\right\} x-\sigma_{2}(x) g(x)-\epsilon_{2}\|x\|^{2}
\end{aligned}
$$

は SOS. (35)

このとき, システム $(28)$ の原点は, 領域 $X$ において局所漸 近安定である。

\section{5. 数值実験による安定化ゲインの限界評価}

本章では，前章で述べた多項式二乗和を用いた安定性解析 の数值実験結果について述べる。具体的には遷移沸騰領域に おける冷却制御の安定限界を求める数值シミュレーションの 結果について考察する。

数值実験は, MATLAB, 多項式二乗和のための数值解析 ッール SOSTOOLS ${ }^{22)}$ および SeDuMi ${ }^{23)}$ を用いて実施し た。数值実験のパラメータを Table 1 に示す.

目標温度 $\theta_{\text {aim }}$ は目標巻取温度 $C T_{\text {aim }}$ から決定される. 固定 した積分時間 $T_{I}$ に対して, 安定化ゲイン $K_{P}$ の最大值 $K_{\max }$ を系 2 に基づく多項式二乗和を用いた安定性解析により計算 した．具体的には，固定した $T_{I}$ のもとで, $K_{P}$ を漸増させて系 2 の判定条件を適用し, 安定限界となるゲインを数值的に求め た。条件 $\left(C T_{\mathrm{aim}}, \gamma\right)=(450,30)$ の場合には, $K_{\max }=0.15$ が得られ, 以下のような Lyapunov 関数 $V(x)$ が見つかった.

$$
\begin{aligned}
& V(x)=x^{T} P x, \\
& P=\left[\begin{array}{cccc}
95.88 & 13.27 & -6.90 & 7.24 \\
13.27 & 3.04 & -0.93 & 1.42 \\
-6.90 & -0.93 & 2.88 & -0.33 \\
7.24 & 1.42 & -0.33 & 1.93
\end{array}\right] .
\end{aligned}
$$

パラメータ $\gamma$ の $K_{\max }$ に対する影響を Table 2 に示す. 目標巻取温度 $C T_{\text {aim }}$ を 450 に固定して, $\gamma$ の值を 1 から 30 に変化させた．パラメータ $\gamma$ は領域 $X$ の大きさを決定する ので, プロセスゲインがより広い範囲で変動する条件のもと で安定性を保証するには許容ゲインの最大值は小さくせねば 
Table 2 Maximum stabilizing gain $\left(C T_{\text {aim }}=450\right)$

\begin{tabular}{|c|c|c|c|c|c|}
\hline$\gamma$ & 1 & 5 & 10 & 15 & 30 \\
\hline$K_{\max }$ & 0.183 & 0.175 & 0.170 & 0.165 & 0.150 \\
\hline
\end{tabular}

Table 3 Maximum stabilizing gain $(\gamma=30)$

\begin{tabular}{|c|c|c|c|c|c|}
\hline$C T_{\text {aim }}$ & 450 & 475 & 500 & 525 & 550 \\
\hline$K_{\max }$ & 0.150 & 0.159 & 0.168 & 0.179 & 0.188 \\
\hline
\end{tabular}

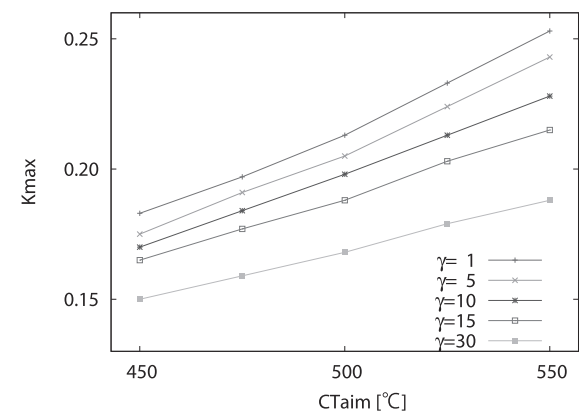

Fig. $9 K_{\max }$ vs. $C T_{\text {aim }}$ for different $\gamma$ values

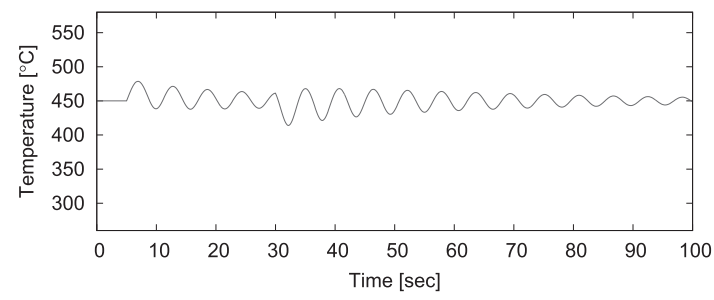

(a) $K_{P}=0.9^{*} K_{\max }$

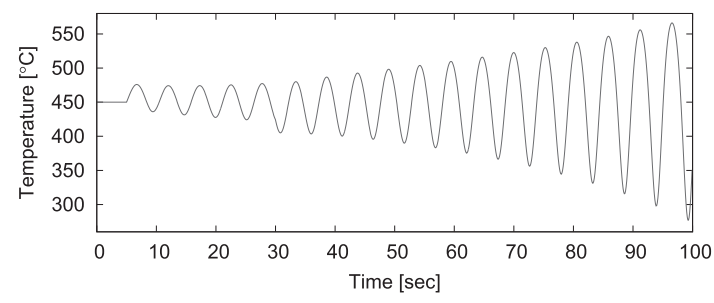

(b) $K_{P}=1.1 * K_{\max }$

Fig. 10 Time response of strip temperature $\left(C T_{\text {aim }}=450\right)$

ならないことがわかる．

つぎに $C T_{\text {aim }}$ と $K_{\max }$ の関係を調べた結果を Table 3 に 示す. 目標巻取温度 $C T_{\text {aim }}$ が増加するにつれ, MHF 点に近 づくのでプロセスゲインの值は小さくなる，したがって，相 対的に大きな比例ゲインを用いることができる.

目標巻取温度 $C T_{\text {aim }}$ およびパラメータ $\gamma$ を変化させた場 合の $K_{\max }$ を Fig. 9 に示す。目標巻取温度 $C T_{\text {aim }}$ が低いほ ど，また， $\gamma$ を大きく取れば， $K_{\max }$ が小さくなることがわ かる.

目標巻取温度 $C T_{\text {aim }}=450$ で，ステップ状の外乱が $5 \sim$ $30 \mathrm{sec}$ の間に印加された場合の応答を数值シミュレーション により求めた。比例ゲイン $K_{P}$ を限界ゲイン $(\gamma=1$ の場合 の $\left.K_{\max }\right)$ の 0.9 倍および 1.1 倍とした場合の数值実験結果 を Fig. 10 の (a)(b) に示す. 比例ゲイン $K_{P}$ を限界ゲイン の 1.1 倍とした場合には, 制御系が不安定になる。また，同

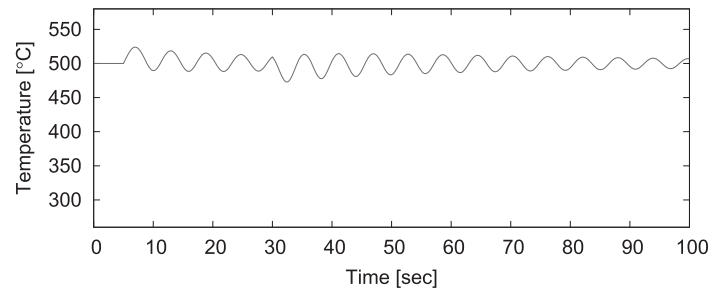

Fig. 11 Time response of strip temperature $\left(C T_{\text {aim }}=500\right)$

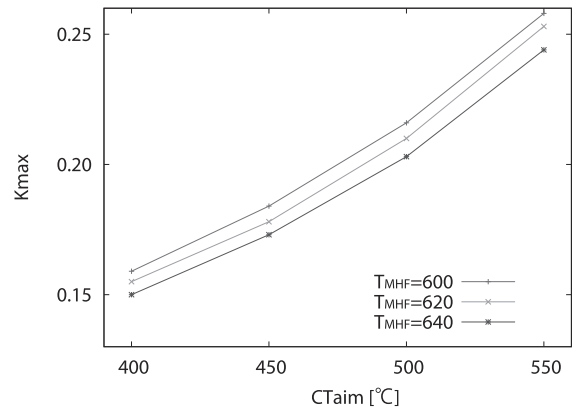

Fig. $12 K_{\max }$ vs. $C T_{\text {aim }}$ for different $T_{\mathrm{MHF}}$ values $(\gamma=1)$

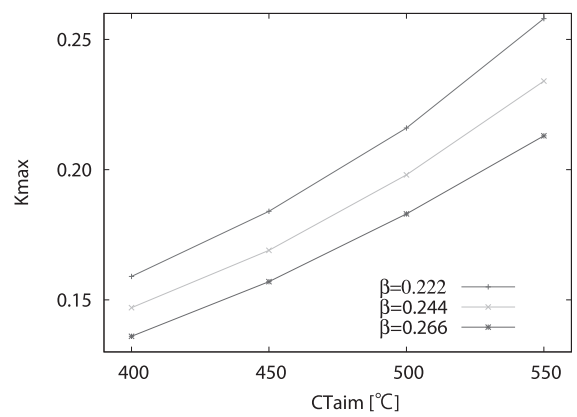

Fig. $13 K_{\max }$ vs. $C T_{\text {aim }}$ for different $\beta$ values $(\gamma=1)$

じゲインを目標巻取温度 $C T_{\text {aim }}=500$ の場合に用いた結果 をFig. 11 に示すが，この場合には応答は不安定とはならな い。これらの結果より，得られた安定化ゲインの評価は妥当 で，保守的すぎないことがいえる．以上より，目標巻取温度 が遷移沸騰領域にある場合には，目標巻取温度が低くなるほ ど PI 制御器の比例ゲインを低目に抑える必要があることが わかる。

冷却工程のプロセスゲイン $K_{C}$ は $(15)$ 式でモデル化され ているので, $\mathrm{MHF}$ 点 $T_{\mathrm{MHF}}\left(=F T-\theta_{\mathrm{MHF}}\right)$ に依存する. $\mathrm{MHF}$ 点 $T_{\mathrm{MHF}}$ が高くなれば， $K_{\max }$ の值は Fig. 12 に示す ように $C T_{\mathrm{aim}}$ の各点で小さくなる.

また，プロセスゲイン $K_{C}$ の変化はパラメータ $\beta$ に依存す るので， $\beta$ に対する $C T_{\text {aim }}$ と $K_{\max }$ の関係を図示したもの を Fig. 13 に示す. パラメータ $\beta$ が大きくなるほど， $K_{\max }$ は小さくなることがわかる，パラメータ $\beta$ はプロセスゲイン の温度依存性の度合を表わすものと考えることができるので， 鋼種による鋼板表面性状などが原因で，プロセスゲインの温 度依存性が高くなった場合には制御ゲインをより小さくする 必要が出てくる. 


\section{6. 結言}

本論文では，遷移沸騰領域における冷却制御をプロセスゲ インが鋼板温度で変化する非線形状態空間モデルで表現し， 多項式二乗和を用いた安定性解析を行なった。 目標温度が遷 移沸騰領域にある場合には, 目標温度が低くなるほど PI 制 御器の比例ゲインを低目に抑える必要があることを数值実験 結果とともに示した。

今回は制御器を PI 制御器に限定して安定性解析を行なっ たが，遷移沸騰領域でのプロセスゲイン変化を考慮に入れた 状態フィードバック制御系設計については現在検討中である. さらに沸騰曲線 (Fig. 3) 全体を, より高次の非線形関数で近 似した，適用範囲の広いモデルに基づく検討も今後の課題と したい.

\section{参 考 文 献}

1) F. Hollander: Design and control for advanced runout table processing, Iron and Steel Engineer, 48-3, 81/92 (1971)

2) 高橋亮一：鉄鋼業に扔ける制御，コロナ社 (2002)

3）中川, 橘: ホットストリップミルに抢ける鋼板の高精度ダイナ ミック冷却履歴制御, 計測自動制御学会論文集, 45-4, 233/240 (2009)

4）今成, 藤山: 熱間薄板圧延に打ける巻取り温度制御, 電学論 D, 125-12, 1105/1112 (2005)

5) T. Tsukuda, Y. Nishida, T. Shirasaki, S. Nishino, H. Hasegawa, M. Kobayashi, K. Doi and T. Okuno: Development of cooling control technology on hot strip mill, Proceedings of the 10th International Conference on Steel Rolling, 507/512 (2010)

6) E.N. Hinrichsen: Hot strip mill runout table cooling-A system view of control, operation, and equipment, Iron and Steel Engineer, 53-10, 29/34 (1976)

7）成田, 秋山, 大和田, 堀, 寺本: 緩冷却ノズルの開発（緩冷却を 用いた高精度巻取温度制御 第 2 報), CAMP-ISIJ, 6, 1442 (1993)

8）成田, 加藤, 秋山, 大和田, 見崎, 寺本 : 緩冷却を用いた高精 度巻取温度制御，CAMP-ISIJ, 7, 431/434 (1994)

9) S. Prajna, A. Papachristodoulou and F. Wu: Nonlinear Control Synthesis by Sum of Squares Optimization: A Lyapunov-based Approach, Proc. ASCC, WM3 (2004)

10）加藤, 平田, 杉本：状態依存むだ時間系の非線形モデル表現 と SOS 解析, システム制御情報学会論文誌, 21-4, 103/110 (2008)

11）大石泰章: 2 乗和多項式に基づくロバスト制御系設計, SICE セミナー「実践的な制御系設計一(ポスト) ロバスト制御の最 前線一」テキスト， $71 / 88$ (2007)

12）青木, 高見, 大石：2 乗和多項式に基づくクレーンのゲインス ケジュールド制御, 計測自動制御学会論文集, 45-4, 208/214 (2009)

13）市原, 川田：SOS に基づくアクロボットのゲインスケジュー リング制御—姿勢制御実験による検証一, 計測自動制御学会 論文集，46-7, 373/382 (2010)

14）中川, 焼田, 橘: 熱延鋼板の巻取温度制御方法, 特開 2000$317513 ， 2000.11 .21$ (特許第 3480366 号，2003.10.10）

15) V.K. Dhir and G.P. Purohit: Subcooled film-boiling heat transfer from sphere, Nucl. Eng. Des., 47-1, 49/66 (1978)

16) E.K. Kalinin, I.I. Berlin and V.V. Kostiouk: Transition boiling heat transfer, Adv. Heat Transf., 18, 241/323 (1987)

17）加藤, 網野, 富山, 秋山, 堀, 柏崎: 熱延冷却制御システムの開
発（緩冷却を用いた高精度巻取温度制御－1），CAMP-ISIJ， 6, 1441 (1993)

18) M. Ono, T. Kurokawa, F. Hirao, E. Takeda and K. Nakano: The computer control system of hot strip coiling temperature, IFAC 7th World Congress, 159/166 (1978)

19）高橋, 大島, 橘, 本城, 山本, 木村, 蔵町 : ホットラン冷却制 御システムの開発，鉄と鋼，71-12, S1152 (1985)

20）本田，植松，橘，中川，武衛，阪上，木村，高橋：熱延冷却帯 内の注水環境下における鋼板温度計測技術（ファウンテン・パ イロメーター）の開発，鉄と鋼，96-10,592/600 (2010)

21）中川, 橘, 本田, 植松: 熱延冷却帯内の注水環境下における鋼 板温度測定手段を用いた巻取温度制御，計測自動制御学会論文 集, 46-8, 463/471 (2010)

22) S. Prajna, A. Papachristodoulou and P.A. Parrilo: Introducing SOSTOOLS: A general purpose sum of squares programming solver, Proc. IEEE CDC, 741/746 (2002)

23) J.F. Sturm: Using SeDuMi 1.02, a MATLAB toolbox for optimization over symmetric cones, Optimization Methods and Software, 11-12, 625/653 (1999)

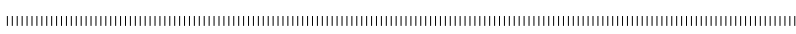

$$
\text { [著 者 紹 介] }
$$

中 川繁 政 (正会員)

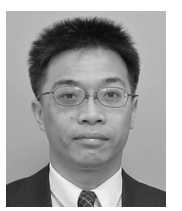

1987 年京都大学大学院工学研究科数理工学専 攻修士課程修了．同年住友金属工業 (株) に入社. 鉄鋼圧延プロセスの制御技術の研究開発に従事. 2011 年奈良先端科学技術大学院大学情報科学研究 科博士後期課程修了。博士 (工学)。92 年, 2008 年, 2010 年, 2011 年計測自動制御学会技術賞, 2011 年日本鉄鋼協会俵論文賞，2012 年日本鉄鋼 協会学術記念賞 (白石記念賞), 2012 年第 4 回もの づくり日本大賞優秀賞を受賞. 日本鉄鋼協会会員.

\section{平田 健太郎（正会員）}

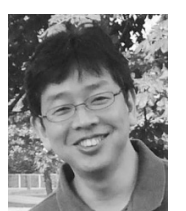

1990 年京都大学大学院工学研究科数理工学専攻 修士課程修了. 住友金属工業 (株), 京都大学大学 院工学研究科数理工学専攻博士課程, 同大学院応 用システム科学専攻助手, 大阪府立大学工学部電気 電子システム工学科講師を経て, 2005 年奈良先端 科学技術大学院大学情報科学研究科助教授, 2007 年より准教授. むだ時間系, 遅延フィードバック 制御拧よびメカトロ系の制御応用などの研究に従 事. 博士 (工学). 97 年計測自動制御学会論文賞 武田賞，2005 年，2010 年システム制御情報学会 論文賞を受賞. システム制御情報学会，IEEE の 会員.

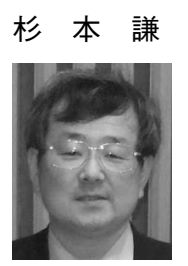

二 (正会員)

1982 年京都大学大学院工学研究科数理工学専攻 修士課程修了後, 三菱電機, 京都大学, 岡山大学, 名古屋大学を経て奈良先端科学技術大学院大学教 授となり現在に至る。制御理論に関する研究に従 事. 工学博士. 2007 年計測自動制御学会論文賞, 2010 年システム制御情報学会論文賞を受賞.シス テム制御情報学会, IEEE などの会員. 